\title{
KAJIAN SOSIODIALEKTOLOGI BAHASA MASYARAKAT HADRAMIY (STUDI KASUS MASYARAKAT INDONESIA KETURUNAN ARAB DI PASAR KLIWON SURAKARTA)
}

\author{
Hanifah Nida'uljanah \\ hanifah.nidauljanah@gmail.com \\ Muhammad Ridwan \\ muh.ridwan.1987@gmail.com \\ Program Studi Sastra Arab \\ Fakultas Ilmu Budaya Universitas Sebelas Maret
}

\begin{abstract}
This research examines the genetic relationship and separating time of language used by generation of Arab in Pasar Kliwon Surakarta along Arabic language. The data source of this research is Hadramy community in Arabic Department Universitas Sebelas Maret and group of pupils of Hadramy generation studying in SMA Islam Diponegoro Surakarta. The collecting data was done by talking technique and calling up the questions, and continued by noting and recording data. The analyzing data used phonetic equalizing method. The results of the research reveal, first, Pasar Kliwon'n language has historic relationship to Arabic language. The research finds 136 couple words that have genetic relationship among 200 Swadesh used vocabularies, or $68 \%$ among them. It clear to be concluded that relationship occurred between two variants of that language. Second, the separating time of language was predicted taking place in 1011 to 1207 (counted from 2017).
\end{abstract}

Keywords: genetic relationship of language, separating time, Hadramy community, Pasar Kliwon, Arabic language.

$$
\begin{aligned}
& \text { ملخص } \\
& \text { يتناول هذ البحث علاقة القرابة والمدة اللغوية المنفصلة التى استخدمها المجتمع المنسوب إلى العرب فن باسار }
\end{aligned}
$$

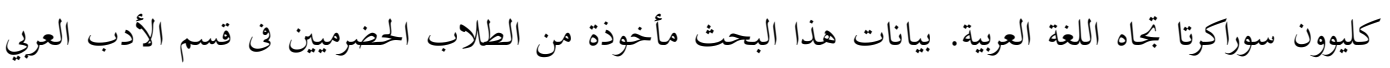

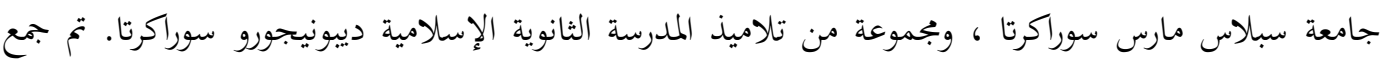

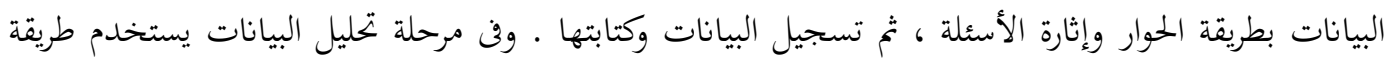

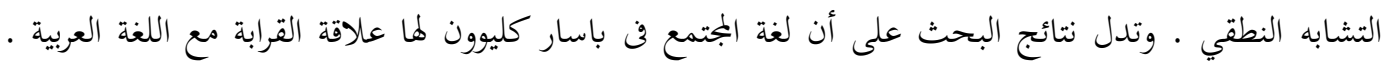

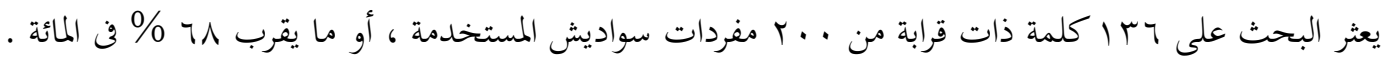

$$
\begin{aligned}
& \text { هذه النسبة تدل على وجود القرابة بين لهجة باسار كليوون واللغة العربية ـ أما المدة اللغوية المنفصلة بين اللغتين }
\end{aligned}
$$

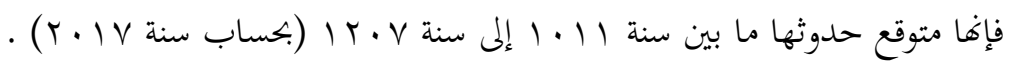

$$
\begin{aligned}
& \text { الكلمات المفتاحية : القرابة اللغوية ، المدة المنفصلة ، المجتمع الحضرمي ، باسار كليوون ، اللغة العربية . }
\end{aligned}
$$




\section{PENDAHULUAN}

Indonesia merupakan negara yang wilayahnya sangat luas dengan penduduk yang terdiri dari berbagai etnis, baik etnis asli maupun etnis pendatang, salah satunya yaitu Arab. Zunainingsih (2010: 18) mengungkapkan, kedatangan etnis Arab ke Indonesia diperkirakan terjadi sejak abad pertengahan (abad ke-13). Tujuan awal kedatangannya adalah untuk berdagang sekaligus berdakwah yang kemudian secara berangsur-angsur mulai menetap dan berkeluarga dengan masyarakat setempat. Masyarakat keturunan Arab yang bermukim di Nusantara berasal dari Hadramaut, Yaman, sehingga disebut dengan masyarakat Hadramiy (Widyastuti, 2006: $15)$.

Masyarakat Hadramiy diperkirakan masuk ke Surakarta pada abad ke-19 dengan penempatan yang diatur oleh kerajaan Kasunanan Surakarta dan tidak terlepas dari kebijakan kolonial Belanda. Hal tersebut mengakibatkan penempatannya yang terpisah dengan masyarakat setempat. Pemukiman ini selanjutnya bukan lagi merupakan pemukiman eksklusif dan tersebar merata di antara penduduk etnis Jawa (Zunainingsih, 2010: 18-20). Penyebaran pemukiman ini menyebabkan kelompok minoritas Arab melakukan interaksi dengan kelompok Jawa.

Interaksi merupakan hal yang manusiawi bagi pendatang terhadap masyarakat setempat untuk melanjutkan hidup di tempat yang baru dan melaksanakan berbagai kegiatan. Beragamnya kegiatan tersebut mengharuskan untuk melakukan komunikasi satu sama lain. Padahal, bahasa yang digunakan oleh masyarakat Hadramiyberbeda dengan masyarakat setempat. Bahasa yang digunakan oleh masyarakat Hadramiy tersebut adalah bahasa Arab, sedangkan bahasa yang digunakan masyarakat setempat adalah bahasa Jawa. Perbedaan kedua bahasa di dalam satu lingkungan tersebut menyebabkan terjadinya kontak bahasa yang memunculkan suatu bahasa komunikasi baru yang digunakan oleh masyarakat Hadramiy. Penelitian ini menyebutnya dengan bahasa Pasar Kliwon Surakarta.

Chaer dan Agustina (2010: 84) berpendapat bahwa peristiwa-peritiwa kebahasaan yang mungkin terjadi sebagai akibat adanya kontak bahasa adalah peristiwa bilingualisme, diglosia, alih kode, campur kode, interferensi, integrasi, konvergensi, dan pergeseran bahasa. Peristiwa kebahasaan tersebut dapat dilihat dari kosakata yang digunakan oleh masyarakat Hadramiy dalam berkomunikasi sehari-hari. Oleh karena itu, penelitian ini memfokuskan pada kosakata bahasa tersebut untuk dilakukan peneropongan secara statistik untuk menetapkan pengelompokannya berdasarkan persentase kesamaan dan perbedaannya dengan bahasa Arab fuscha.

Berdasarkan fenomena tersebut, maka ditemukan hal yang menarik untuk diamati dalam permasalah ini, yaitu fenomena relasi kekerabatan bahasa Pasar Kliwon Surakarta dengan bahasa Arab. Bahasa Pasar Kliwon Surakarta berasal dari bahasa Arab yang telah mengalami perubahan atau penyesuaian terhadap bahasa pribumi, tetapi kepastian mengenai usia bahasa tersebut belum diketahui, terlebih tidak memiliki naskah-naskah kuno. Usia tersebut dapat menunjukkan waktu kedua bahasa tersebut mulai berpisah dari bahasa yang sama. Adapun waktu berpisah tersebut dapat menunjukkan pula waktu kedatangan masyarakat Hadramiy ke Indonesia sehingga hasil penelitian ini dapat mendukung dan memperkuat salah satu teori kedatangan masyarakat tersebut ke negara ini, sehubungan dengan banyaknya teori yang mengatakannya. Waktu tersebut pula yang menunjukkan bahasa Pasar Kliwon mulai melakukan kontak.

Berdasarkan latar belakang tersebut, penelitian ini berusaha menjawab mengenai hubungan kekerabatan bahasa Pasar Kliwon dengan bahasa Arab fuscha dan waktu kedua 
bahasa tersebut mulai berpisah. Adapun manfaat dari penelitian ini adalah untuk mengetahui besar kekerabatan bahasa Pasar Kliwon dan bahasa Arab, begitu juga waktu pisah kedua bahasa tersebut dari bahasa yang sama, untuk mengembangkan kajian terhadap bahasa pendatang, dan diharapkan dapat membuka wawasan kepada masyarakat luas bahwa melalui penggunaan kosakata bahasa suatu tempat dapat memperlihatkan hubungannya dengan bahasa lain.

Berdasarkan tujuan tersebut, penelitian ini menggunakan teori leksikostatistik. Leksikostatistik merupakan cara pengelompokan bahasa yang dilakukan dengan menghitung persentase perangkat kognat (Mahsun, 1995: 115). Begitu juga Parera (1991: 105) menyatakan leksikostatistik adalah suatu teknik dalam pengelompokan bahasa yang lebih cenderung mengutamakan peneropongan kata-kata (leksikon) secara statistik, untuk kemudian berusaha menetapkan pengelompokkan itu berdasarkan persentase kesamaan dan perbedaan suatu bahasa dengan bahasa lain (Keraf, 1996: 121). Leksikostatistik dapat digunakan dalam penelitian dialektologi untuk pengelompokan daerah pengamatan sebagai pemakai dialek atau subdialek tertentu dengan menghitung persentase kekognatan antardaerah tersebut (Mahsun, 1995: 116).

Keraf (1996: 128) menyatakan bahwa sebuah pasangan kata akan dinyatakan kerabat bila memenuhi salah satu ketentuan, yaitu pasangan itu identik, pasangan itu memiliki korespondensi fonemis, kemiripan secara fonetis, atau satu fonem berbeda. Setelah menetapkan kata-kata kerabat dengan prosedur seperti yangdikemukakan di atas, maka dapat ditetapkan besarnya persentase dari keduabahasa yang dibandingkan.

Persentasi kekerabatan tersebut dapat menjelaskan status kedua bahasa yang diteliti. Penentuan tingkatan jarak bahasa tersebut dilakukan berdasarkan klasifikasi di bawah ini (Ayahtrohaedi, 1983: 32):

\begin{tabular}{|c|l|l|}
\hline No & $\begin{array}{c}\text { Tingkat } \\
\text { pengelompokan }\end{array}$ & $\begin{array}{c}\text { Persentase } \\
\text { kata kerabat }\end{array}$ \\
\hline 1 & Bahasa & $81-100 \%$ \\
\hline 2 & Dialek & $51-80 \%$ \\
\hline 3 & Subdialek & $31-50 \%$ \\
\hline 4 & Wicara & $21-30 \%$ \\
\hline 5 & $\begin{array}{l}\text { Tidak ada } \\
\text { perbedaan }\end{array}$ & $<21 \%$ \\
\hline
\end{tabular}

Persentasekekerabatan juga dapat digunakan untuk menghitung waktu pisah kedua bahasa yang dibandingkandari bahasa yang sama dengan menggunakan rumus: (Keraf, 1996: 130 dan Parera, 1991: 108)

$$
\mathrm{W}=\frac{\log \cdot C}{2 \log \cdot r}
$$

Keterangan:

$w=$ waktu pisah dalam ribuan tahun yang lalu

$r$ =retensi atau persentase konstan dalam 1000 tahun, atau juga disebutindeks, dalam hal ini retensi yaitu $80,5 \%$

$\log =$ logaritma dari,

$\log$, dapat dicari menggunakan tabel logaritma atau menggunakankalkulator.

Namun lebih efektif jika menggunakan kalkulator.

$\mathrm{C}=$ persentase kerabat

$2=$ pembagi waktu pisah dari

kedua bahasa

Hasil dari menghitung waktu pisah dengan menggunakan cara di atas belum menunjukkan kepastian mengenai waktu pisah antara bahasa Pasar Kliwon Surakarta dengan bahasa Arab, maka harus dilakukkan penghitungan selanjutnya menggunakan rumus menghitung jangka kesalahan. Keraf (1996:132) mengatakanbahwa untuk menghitung jangka kesalahan biasanya dipergunakan kesalahanstandar, yaitu $70 \%$ dari kebenaran yang diperkirakan. 
Kesalahan standardiperhitungkan dengan rumus : (Keraf, 1996: 132)

$$
\mathrm{S}=\sqrt{\frac{C(1-C)}{n}}
$$

Keterangan :

$\mathrm{S}=$ kesalahan standar dalam persentase kata kerabat

$\mathrm{C}=$ persentase kata kerabat

$$
\mathrm{N}=\text { jumlah }
$$

kata yang diperbandingkan (baik kerabat maupun non kerabatatau kata yang memiliki pasangan)

Adapun langkah dalam melaksanakan penelitian ini mencakup tiga tahapan (Sudaryanto, 2015: 6-8). Pertama, tahap penyediaan data menggunakan metode cakap dan teknik pancing dengan teknik lanjutan yaitu teknik cakap semuka untuk mendapatkan data lisan berupa 200 kata Swadesh (Sudaryanto, 2015: 208-209). Kedua, tahap analisis data menggunakan metode padan dan teknik bagi unsur penentu (PUP) (Sudaryanto, 2015: 25). Terakhir, tahap penyajian hasil analisis data menggunakan metode informal dan formal (Sudaryanto, 2015: 241).

\section{HASIL ANALISIS DAN PEMBAHASAN}

Hubungan kekerabatan antara bahasa Pasar Kliwon Surakarta dengan bahasa Arab dapat dilihat dari bentuk kosakata dan maknanya. Penentuan kekerabatan dalam penelitian ini menggunakan data kata Swadesh sebanyak 200 kata. Daftar kata tersebut disusun oleh Morris Swadesh. Penelitian ini menggunakan daftar kata Swadesh karena terdiri dari kata-kata non-kultural serta retensi kata dasarnya telah diuji dalam bahasa-bahasa yang memiliki naskah tertulis. Data tersebut dianalisis secara leksikostatistik untuk mendapatkan tingkat persentase kekerabatan antara bahasa Pasar Kliwon dengan bahasa Arab, klasifikasi bahasa, dan waktu pisah dengan jangka kesalahan.

1. Penentuan kata kerabat
Berdasarkan 200 kosakata Swadesh yang dicatat untuk bahasa Pasar Kliwon Surakarta dan bahasa Arab terdapat pasangan kata yang lengkap atau memiliki padanan kata dari kedua bahasa tersebusehingga semua kosakata swadesh dapat diperhitungkan dalam penetapan kata kerabat atau non-kerabat. Adapun syarat glos yang dapat diperhitungkan dalam penentuan kekerabatan kata yaitu bukan berupa kata-kata kosong, bukan kata pinjaman, dan berupa kata dasar (bukan kata jadian).

Apabila data-data tersebut telah terkumpul dan terbebas dari glos yang tidak dapat diperhitungkan, maka langkah selanjutnya yaitu pengisolasian morfem terikat. Pengisolasian morfem terikat membuat lebih mudah dalam penentuan pasangan kata yang menunjukkan kesamaan dan tidak sehingga kata yang digunakan untuk perbandingan yaitu berupa kata dasar.

Apabila langkah sebelumnya telah terlewati, maka dapat dilakukan penentuan kekerabatan antara kedua bahasa tersebut. Sebuah pasangan kata dapat dinyatakan sebagai kata kerabat apabila memenuhi syarat, yaitu identik, memiliki korespondensi fonemis, mempunyai kemiripan fonetis, dan mempunyai satu fonem yang berbeda.

\subsection{Pasangan kata identik}

Salah satu ketentuan dalam menetapkan pasangan kata sebagai kata kerabat adalah pasangan kata tersebut memiliki kemiripan identik. Identik dalam hal ini adalah pasangan tersebut memiliki fonem, bunyi, dan makna yang sama persis. Pasangan kata tersebut tidak mengalami perubahan pada kedua bahasa.

\begin{tabular}{|l|l|l|}
\hline \multicolumn{1}{|c|}{ Glos } & $\begin{array}{c}\text { Bahasa } \\
\text { PKS }\end{array}$ & \multicolumn{1}{|c|}{ Bahasa Arab } \\
\hline Batu & {$[$ hajar $]$} & {$[$ hajar $]$} \\
\hline Besar & {$[$ kabir $]$} & {$[$ kabi:r $]$} \\
\hline Karena & {$[$ li?ana $]$} & {$[$ li $?$ anna $]$} \\
\hline Lima & {$[$ xOmsah $]$} & {$[$ xamsah $]$} \\
\hline Pohon & {$[$ šajarOh $]$} & {$[$ šajarah $]$} \\
\hline Sungai & {$[$ nahor $]$} & {$[$ nahr $]$} \\
\hline
\end{tabular}


Berdasarkan pemakaiannya, bahasa Pasar Kliwon Surakarta menghilangkan tekanan pada silabe berat dan diikuti penghilangan pembedaan vokal panjang dan pendek. Vokal panjang atau pendek digunakan sesuai dengan intonasi kalimat (Fauziah, 2006 dan Adabiyyat, 2011: 228). Hal ini tidak membedakan keidentikan kata tersebut.

Hal yang sama terjadi pada kemunculan vokal [O] setelah fonem [r], $[\mathrm{T}]$, $[\mathrm{x}]$, dan $[\Upsilon]$, dan kemunculan bunyi vokal [ə] diantara dua konsonan berjejer di belakang kata. Kedua hal tersebut juga tidak mempengaruhi keindetikan kata dengan pasangannya, karena apabila diperhatikan, bunyi yang dihasilkan pada setiap pasangan kata tersebut sama.

\subsection{Pasangan kata yang memiliki korespondensi fonemis \\ Pasangan kata yang memiliki} korespondensi fonemis merupakan pasangan kata yang memiliki hubungan antara kedua bahasa berdasarkan posisi fonem-fonem yang berupa alofon dan makna yang sama dari kedua bahasa yang dibandingkan. Sehingga dapat diperoleh sejumlah perangkat korespondensi, sesuai dengan besar atau panjang segmen dari bahasa Pasar Kliwon Surakarta dan bahasa Arab.

\begin{tabular}{|c|c|c|}
\hline Glos & $\begin{array}{c}\text { Bahasa } \\
\text { PKS }\end{array}$ & $\begin{array}{c}\text { Bahasa } \\
\text { Arab }\end{array}$ \\
\hline Angin & {$[r \boldsymbol{r} h]$} & {$[r i: h]$} \\
\hline Benar & {$\left[s S^{\prime} \mathrm{h} h\right]$} & [şahi:h] \\
\hline Dua & [?iӨncn] & [iOnaini] \\
\hline Dekat & {$[$ garrb] } & [qari:b] \\
\hline Diri(ber) & [g $\sigma m]$ & [qum] \\
\hline
\end{tabular}

\footnotetext{
1.3. Pasangan kata yang memiliki kemiripan fonetis

Pasangan kata yang memiliki kemiripan fonetis merupakan pasangan kata yang memilikikemiripan fonetis pada posisi artikulatoris yang sama.
}

\begin{tabular}{|l|l|l|}
\hline \multicolumn{1}{|c|}{ Glos } & \multicolumn{1}{|c|}{$\begin{array}{c}\text { Bahasa } \\
\text { PKS }\end{array}$} & \multicolumn{1}{c|}{$\begin{array}{c}\text { Bahasa } \\
\text { Arab }\end{array}$} \\
\hline Anak & {$[$ walat $]$} & {$[$ walad $]$} \\
\hline Awan & {$[$ sahap $]$} & {$[$ sahab $]$} \\
\hline Tua & {$[$ ?ajus $]$} & {$[$ ?aju:z $]$} \\
\hline
\end{tabular}

1.4. Pasangan kata dengan satu fonem berbeda

Pasangan kata dengan satu fonem yang berbeda yaitu apabila dapat dijelaskan perbedaannya. Apabila dalam satu pasangan terdapat perbedaan satu fonem, tetapi dapat dijelaskan bahwa perbedaan tersebut terjadi karena pengaruh lingkungan yang dimasukinya, sedangkan dalam bahasa lain pengaruh tersebut tidak mengubah fonemnya, maka pasangan itu dapat ditetapkan sebagai kata kerabat. Maksut dari fonem yang berbeda yaitu fonem pada suatu kata berbeda dari fonem pada kata pasangannya, bukan merupakan alofon, dan juga tidak memiliki kesamaan posisi artikulasi.

\begin{tabular}{|l|l|l|}
\hline \multicolumn{1}{|c|}{ Glos } & \multicolumn{1}{c|}{$\begin{array}{c}\text { Bahasa } \\
\text { PKS }\end{array}$} & \multicolumn{1}{c|}{$\begin{array}{c}\text { Bahasa } \\
\text { Arab }\end{array}$} \\
\hline Bunuh & {$[$ gətal $]$} & {$[$ qatl $]$} \\
\hline Kami & {$[$ nahna $]$} & {$[$ nahnu $]$} \\
\hline Kamu & {$[$ ?ente $]$} & {$[$ ?anta $]$} \\
\hline
\end{tabular}

Berdasarkan 4 ketentuan tersebut, maka dapat dilakukan penentuan kata kerabat berikut ini dengan menggunakan kode penanda (A) dan (B). Apabila pasangan kata di antara kedua bahasa berkerabat maka ditandai dengan kode (A) dan (A). Apabila pasangan kata di antara kedua bahasa tidak berkerabat maka ditandaidengan kode (A) dan (B). Penghitungan jumlah kata kerabat dapat dilakukan dengan melihat kesamaan penanda antar kata kerabat bahasa tersebut pada tabel di bawah. 
Jurnal CMES Volume X Nomor 2 Edisi Juli - Desember 2017

\begin{tabular}{|c|c|c|c|c|c|c|c|c|c|}
\hline No & Glos & $\begin{array}{c}\text { Bahasa } \\
\text { PKS }\end{array}$ & $\begin{array}{c}\text { Bahasa } \\
\text { Arab }\end{array}$ & Kete & gan & K1 & K2 & $\mathbf{K 3}$ & K4 \\
\hline 1 & Abu & {$[? a b u]$} & {$[\mathrm{rama \overline {d }}]$} & $\mathrm{A}$ & $\mathrm{B}$ & & & & \\
\hline 2 & Air & [ma?] & {$[m \bar{a} ?]$} & A & A & $\wedge$ & & & \\
\hline 3 & Akar & [? uşul] & [?uşūl] & A & $\mathrm{A}$ & $\wedge$ & & & \\
\hline 4 & Alir(me) & {$[\operatorname{alir}(\eta)]$} & [yasīlu] & A & B & & & & \\
\hline 5 & Anak & [walat] & [walat] & A & $\mathrm{A}$ & & & $\wedge$ & \\
\hline 6 & Angin & {$[r I h]$} & {$[r \bar{i} h]$} & A & $\mathrm{A}$ & $\wedge$ & & & \\
\hline 7 & Anjing & [kalap] & {$[$ kalb] } & $\mathrm{A}$ & $\mathrm{A}$ & & & $\wedge$ & \\
\hline 8 & Apa & {$[\mathrm{ma}]$} & {$[m \bar{a}]$} & $\mathrm{A}$ & $\mathrm{A}$ & $\wedge$ & & & \\
\hline 9 & Api & [nar] & {$[n \bar{a} r]$} & $\mathrm{A}$ & $\mathrm{A}$ & $\wedge$ & & & \\
\hline 10 & Apung(me) & {$[\operatorname{amba\eta }(\eta)]$} & [yaTfūu & $\mathrm{A}$ & $\mathrm{B}$ & & & & \\
\hline 11 & Asap & [?asap] & [duxān] & $\mathrm{A}$ & $\mathrm{B}$ & & & & \\
\hline 12 & Awan & [sahap] & [sahab] & $\mathrm{A}$ & $\mathrm{A}$ & & & $\wedge$ & \\
\hline 13 & Ayah & [?abi] & {$[? a b i]$} & $\mathrm{A}$ & $\mathrm{A}$ & $\wedge$ & & & \\
\hline 14 & Bagaimana & {$[k \varepsilon f]$} & [kaif] & A & $\mathrm{A}$ & & $\wedge$ & & \\
\hline 15 & Baik & {$[x \varepsilon r]$} & [xair] & A & A & & $\wedge$ & & \\
\hline 16 & Bakar & [bakar] & [yahruqu] & $\mathrm{A}$ & $\mathrm{B}$ & & & & \\
\hline 17 & Balik & {$[$ balı? $(m)]$} & [yaqlibu] & $\mathrm{A}$ & $\mathrm{B}$ & & & & \\
\hline 18 & Banyak & [kaAir] & {$[k a \theta \bar{l} r]$} & $\mathrm{A}$ & $\mathrm{A}$ & $\wedge$ & & & \\
\hline 19 & Baring & {$[$ ragot] } & {$[$ ruqū $d]$} & $\mathrm{A}$ & $\mathrm{A}$ & & $\wedge$ & & \\
\hline 20 & Baru & [jadit] & [jadidd] & $\mathrm{A}$ & $\mathrm{A}$ & & & $\wedge$ & \\
\hline 21 & Basah & {$[$ rOtop $]$} & {$[\mathrm{ratb}]$} & $\mathrm{A}$ & $\mathrm{A}$ & & & $\wedge$ & \\
\hline 22 & Batu & [hajar] & [hajar] & $\mathrm{A}$ & $\mathrm{A}$ & $\wedge$ & & & \\
\hline 23 & Beberapa & {$[b a ? \partial t]$} & {$[b a S d]$} & A & $\mathrm{A}$ & & & & $\wedge$ \\
\hline 24 & Belah(me) & {$[\operatorname{bolah}(m)]$} & {$[\check{s} u q \bar{u} q]$} & $\mathrm{A}$ & B & & & & \\
\hline 25 & Benar & [şOhih] & [şahīh] & $\mathrm{A}$ & $\mathrm{A}$ & & $\wedge$ & & \\
\hline 26 & Bengkak & {$[? a b O h]$} & [waramu] & $\mathrm{A}$ & B & & & & \\
\hline 27 & Benih & [bənIh] & $\lceil$ bizru] & $\mathrm{A}$ & B & & & & \\
\hline 28 & Berat & {$[$ [ } & {$[$ [Agīll } & $\mathrm{A}$ & $\mathrm{A}$ & & $\wedge$ & & \\
\hline 29 & Berenang & [sibahah] & [sibāhah] & A & $\mathrm{A}$ & $\wedge$ & & & \\
\hline 30 & Beri & {$[k \varepsilon ? i]$} & {$[y u ? T \bar{l}]$} & $\mathrm{A}$ & $\mathrm{B}$ & & & & \\
\hline 31 & Berjalan & [yamši & [yamši] & $\mathrm{A}$ & $\mathrm{A}$ & $\wedge$ & & & \\
\hline 32 & Besar & [kabir] & [kabīr $]$ & $\mathrm{A}$ & $\mathrm{A}$ & $\wedge$ & & & \\
\hline 33 & Bilamana & [kalo] & {$[? i \delta \bar{a}]$} & $\mathrm{A}$ & B & & & & \\
\hline 34 & Binatang & [hayawan] & [hayawān] & $\mathrm{A}$ & $\mathrm{A}$ & $\wedge$ & & & \\
\hline 35 & Bintang & [bintan] & [najm] & $\mathrm{A}$ & B & & & & \\
\hline 36 & Buah & [fawakıh] & [fawākih] & $\mathrm{A}$ & $\mathrm{A}$ & & $\wedge$ & & \\
\hline 37 & Bulan & [gOmar] & [qamar] & $\mathrm{A}$ & $\mathrm{A}$ & & $\wedge$ & & \\
\hline 38 & Bulu & [bulu] & [rîšun] & A & $\mathrm{B}$ & & & & \\
\hline 39 & Bunga & [zahrOh] & [zahrah] & $\mathrm{A}$ & $\mathrm{A}$ & $\wedge$ & & & \\
\hline 40 & Bunuh & {$[$ gatal] } & {$[$ qatl $]$} & $\mathrm{A}$ & $\mathrm{A}$ & & & & $\wedge$ \\
\hline 41 & Buru(be) & [buru(be)] & [yaqnisu] & $\mathrm{A}$ & B & & & & \\
\hline 42 & Buruk & [murO?bal] & [qabih] & $\mathrm{A}$ & B & & & & \\
\hline 43 & Burung & {$[t O ? I r]$} & [Tā?ir] & $\mathrm{A}$ & $\mathrm{A}$ & & $\wedge$ & & \\
\hline 44 & Busuk & {$[\mathrm{XOm}]$} & {$[x a m]$} & $\mathrm{A}$ & $\mathrm{A}$ & $\wedge$ & & & \\
\hline 45 & Cacing & [cacin] & {$[d \bar{u} d u n]$} & $\mathrm{A}$ & $\mathrm{B}$ & & & & \\
\hline 46 & $\begin{array}{l}\text { Cium } \\
\text { (wanita dan }\end{array}$ & [kibla?] & [kiblā?] & $\mathrm{A}$ & $\mathrm{A}$ & $\wedge$ & & & \\
\hline
\end{tabular}


Jurnal CMES Volume X Nomor 2 Edisi Juli - Desember 2017 Program Studi Sastra Arab FIB UNS Surakarta

\begin{tabular}{|c|c|c|c|c|c|c|c|c|c|}
\hline & bau) & & & & & & & & \\
\hline 47 & Cuci & [cuci] & [Yusl] & $\mathrm{A}$ & B & & & & \\
\hline 48 & Daging & [lahəm] & [lahm] & $\mathrm{A}$ & $\mathrm{A}$ & $\wedge$ & & & \\
\hline 49 & Dan & {$[w a]$} & {$[w a]$} & A & $\mathrm{A}$ & $\wedge$ & & & \\
\hline 50 & Danau & [buhairOh] & [buhairah] & $\mathrm{A}$ & $\mathrm{A}$ & & $\wedge$ & & \\
\hline 51 & Darah & [dam] & {$[$ dam $]$} & $\mathrm{A}$ & $\mathrm{A}$ & $\wedge$ & & & \\
\hline 52 & Datang & [ji?] & [ji?] & $\mathrm{A}$ & $\mathrm{A}$ & $\wedge$ & & & \\
\hline 53 & Daun & {$[$ warOgOh] } & [waraqah] & $\mathrm{A}$ & $\mathrm{A}$ & & $\wedge$ & & \\
\hline 54 & Debu & [bledvk] & {$[$ turāa $b]$} & $\mathrm{A}$ & B & & & & \\
\hline 55 & Dekat & [garıb] & [garīb] & $\mathrm{A}$ & A & & $\wedge$ & & \\
\hline 56 & Dengan & {$[m a ? a]$} & {$\left[m a{ }^{2} a\right]$} & $\mathrm{A}$ & $\mathrm{A}$ & & & & $\wedge$ \\
\hline 57 & Dengar & [yasma?] & [yasmaS] & $\mathrm{A}$ & A & & & & 1 \\
\hline 58 & Di dalam & {$[f i]$} & {$[f i]$} & A & A & $\wedge$ & & & \\
\hline 59 & Di mana & {$[\varepsilon n]$} & [?aina] & A & A & & $\wedge$ & & \\
\hline 60 & Di sini & [huna] & {$[$ hunā $]$} & $\mathrm{A}$ & $\mathrm{A}$ & $\wedge$ & & & \\
\hline 61 & Di situ & [hunak] & [hunāka] & $\mathrm{A}$ & $\mathrm{A}$ & $\wedge$ & & & \\
\hline 62 & Pada & {$[$ pada] } & {$[f i]$} & $\mathrm{A}$ & $\mathrm{B}$ & & & & \\
\hline 63 & Dingin & [barit] & [barīd] & $\mathrm{A}$ & $\mathrm{A}$ & & & $\wedge$ & \\
\hline 64 & Diri(ber) & [gणm] & [qum] & $\mathrm{A}$ & A & & $\wedge$ & & \\
\hline 65 & Dorong & {$[\mathrm{dOrO \eta}]$} & {$[d a f G]$} & $\mathrm{A}$ & B & & & & \\
\hline 66 & Dua & [?iӨncn] & [?iOnaini] & $\mathrm{A}$ & A & & $\wedge$ & & \\
\hline 67 & Duduk & {$\left[j l_{I S}\right]$} & [ijlis] & $\mathrm{A}$ & $\mathrm{A}$ & & $\wedge$ & & \\
\hline 68 & Ekor & [?ckOr] & {$[\delta a n a b]$} & $\mathrm{A}$ & B & & & & \\
\hline 69 & Empat & [?arba?ah] & [?arbaSah] & $\mathrm{A}$ & $\mathrm{A}$ & & & & $\wedge$ \\
\hline 70 & Engkau & [?ente] & [?anta] & $\mathrm{A}$ & A & & & & $\wedge$ \\
\hline 71 & Gali & [gali] & [hašara] & $\mathrm{A}$ & $\mathrm{B}$ & & & & \\
\hline 72 & Garam & [garam] & [milh] & $\mathrm{A}$ & B & & & & \\
\hline 73 & Garuk & [garv?] & [yahukku] & $\mathrm{A}$ & $\mathrm{B}$ & & & & \\
\hline 74 & Gemuk & [samin] & {$[\operatorname{samin}]$} & $\mathrm{A}$ & $\mathrm{A}$ & $\wedge$ & & & \\
\hline 75 & Gigi & [?asnan] & [?asnān] & $\mathrm{A}$ & $\mathrm{A}$ & $\wedge$ & & & \\
\hline 76 & Gigit & [gigit] & [yasaddu] & $\mathrm{A}$ & B & & & & \\
\hline 77 & Gosok & {$[\mathrm{gOs} O ?]$} & [yadluku] & $\mathrm{A}$ & B & & & & \\
\hline 78 & Gunung & [jabal] & [jabal] & A & A & $\wedge$ & & & \\
\hline 79 & Hantam & [mukvl] & [yadribu] & $\mathrm{A}$ & B & & & & \\
\hline 80 & Hapus & [masah] & [mash] & $\mathrm{A}$ & $\mathrm{A}$ & $\wedge$ & & & \\
\hline 81 & Hati & [galap] & [qalb] & A & A & & $\wedge$ & & \\
\hline 82 & Hidung & [?anfon] & [?anfun] & $\mathrm{A}$ & $\mathrm{A}$ & & & & $\wedge$ \\
\hline 83 & Hidup & [hayah] & [hayāh] & $\mathrm{A}$ & $\mathrm{A}$ & $\wedge$ & & & \\
\hline 84 & Hijau & {$[\mathrm{ax} \delta \mathrm{Or}]$} & [axdar] & $\mathrm{A}$ & $\mathrm{A}$ & & & & $\wedge$ \\
\hline 85 & Hisap & {$[$ sadOt] } & [yamuşşu] & $\mathrm{A}$ & B & & & & \\
\hline 86 & Hitam & [aswat $]$ & [aswad] & $\mathrm{A}$ & $\mathrm{A}$ & & & $\wedge$ & \\
\hline 87 & Hitung & [hisap] & [hisāb] & $\mathrm{A}$ & A & & & $\wedge$ & \\
\hline 88 & Hujan & [matOr] & [maTar] & $\mathrm{A}$ & A & $\wedge$ & & & \\
\hline 89 & Hutan & [rObah] & [Yābah] & $\mathrm{A}$ & $\mathrm{A}$ & $\wedge$ & & & \\
\hline 90 & Ia & [huwa] & [huwa] & A & A & $\wedge$ & & & \\
\hline 91 & Ibu & [?umi] & [?umi] & $\mathrm{A}$ & $\mathrm{A}$ & $\wedge$ & & & \\
\hline 92 & Ikan & [sama?] & [samak] & $\mathrm{A}$ & $\mathrm{A}$ & & $\wedge$ & & \\
\hline 93 & Ikat & [?ikət] & [raTbah] & $\mathrm{A}$ & $\mathrm{B}$ & & & & \\
\hline 94 & Ini & {$[h a \delta a]$} & {$[h a \delta \bar{a}]$} & A & A & $\wedge$ & & & \\
\hline
\end{tabular}


Jurnal CMES Volume X Nomor 2 Edisi Juli - Desember 2017

Program Studi Sastra Arab FIB UNS Surakarta

\begin{tabular}{|c|c|c|c|c|c|c|c|c|c|}
\hline 95 & Istri & [zavjah] & [zaujah] & $\mathrm{A}$ & $\mathrm{A}$ & & & & $\wedge$ \\
\hline 96 & Itu & [?itu] & 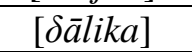 & $\mathrm{A}$ & B & & & & \\
\hline 97 & Jahit & [jahit] & [yah̄̄Tu] & $\mathrm{A}$ & $\mathrm{B}$ & & & & \\
\hline 98 & Jalan(ber) & [yamši & [yamšñ & A & A & $\wedge$ & & & \\
\hline 99 & Jantung & [jantor] & [qalb] & $\mathrm{A}$ & $\mathrm{B}$ & & & & \\
\hline 100 & Jatuh & {$[\mathrm{sagOt}]$} & [saqata] & $\mathrm{A}$ & $\mathrm{A}$ & & $\wedge$ & & \\
\hline 101 & Jauh & {$[b a ? t t]$} & [baSid] & $\mathrm{A}$ & $\mathrm{A}$ & & & & $\wedge$ \\
\hline 102 & Kabut & [kabvt] & {$[d a b \bar{a} b]$} & $\mathrm{A}$ & $\mathrm{B}$ & & & & \\
\hline 103 & Kaki & [rijal] & {$[$ rijl $]$} & A & A & & & & \\
\hline 104 & Kalau & [kalo] & {$[? i \delta \bar{a}]$} & A & B & & & & \\
\hline 105 & Kami & [nahna] & [nahnu] & $\mathrm{A}$ & $\mathrm{A}$ & & & & $\wedge$ \\
\hline 106 & Kamu & [?ente] & [?anta] & $\mathrm{A}$ & $\mathrm{A}$ & & & & $\wedge$ \\
\hline 107 & Kanan & [yamin] & [yamin] & A & A & $\wedge$ & & & \\
\hline 108 & Karena & [li?ana] & [li?anna] & $\mathrm{A}$ & $\mathrm{A}$ & $\wedge$ & & & \\
\hline 109 & Kata(ber) & [kalimah] & [kalimah] & $\mathrm{A}$ & $\mathrm{A}$ & $\wedge$ & & & \\
\hline 110 & Kecil & {$\left[{ }_{s ̧} O Y_{I r}\right]$} & [şaYir] & $\mathrm{A}$ & $\mathrm{A}$ & & $\wedge$ & & \\
\hline 111 & Kelahi(ber) & [za?at $]$ & [nazaSa] & $\mathrm{A}$ & $\mathrm{A}$ & & & & $\wedge$ \\
\hline 112 & Kepala & {$[r O ? \partial s]$} & {$[\mathrm{ra} S \mathrm{~s}]$} & $\mathrm{A}$ & $\mathrm{A}$ & & & & $\wedge$ \\
\hline 113 & Kering & [yabis] & [yābis] & $\mathrm{A}$ & A & $\wedge$ & & & \\
\hline 114 & Kiri & [yasar] & [yasar] & $\mathrm{A}$ & $\mathrm{A}$ & $\wedge$ & & & \\
\hline 115 & Kotor & [wasah] & [wash] & A & $\mathrm{A}$ & $\wedge$ & & & \\
\hline 116 & Kuku & {$[k u k u]$} & {$[d u f r]$} & A & B & & & & \\
\hline 117 & Kulit & [jilat] & [jild] & $\mathrm{A}$ & $\mathrm{A}$ & & & $\wedge$ & \\
\hline 118 & Kuning & [aşfar] & [aşfar] & $\mathrm{A}$ & $\mathrm{A}$ & $\wedge$ & & & \\
\hline 119 & Kutu & [kutu] & [qamlu] & $\mathrm{A}$ & B & & & & \\
\hline 120 & Lain & [lain] & [?axār $\bar{r}$ & $\mathrm{~A}$ & $\mathrm{~B}$ & & & & \\
\hline 121 & Langit & [sama?] & [samā?] & $\mathrm{A}$ & $\mathrm{A}$ & $\wedge$ & & & \\
\hline 122 & Laut & [bahor] & [bahr] & $\mathrm{A}$ & A & $\wedge$ & & & \\
\hline 123 & Lebar & [wast?] & [wasi $\bar{\zeta}\}$ & $\mathrm{A}$ & $\mathrm{A}$ & & & & $\wedge$ \\
\hline 124 & Leher & [leher] & [Gunuq] & $\mathrm{A}$ & $\mathrm{B}$ & & & & \\
\hline 125 & Lelaki & [rojal] & [rijal] & $\mathrm{A}$ & $\mathrm{A}$ & & & & $\wedge$ \\
\hline 126 & Lempar & [?uncal] & [yarmī] & $\mathrm{A}$ & $\mathrm{B}$ & & & & \\
\hline 127 & Licin & [luзи] & [?amlasu] & $\mathrm{A}$ & B & & & & \\
\hline 128 & Lidah & [lisan] & [lisānn] & $\mathrm{A}$ & A & $\wedge$ & & & \\
\hline 129 & Lihat & {$[$ suf] } & {$[r \bar{a} ? a]$} & $\mathrm{A}$ & $\mathrm{B}$ & & & & \\
\hline 130 & Lima & [xOmsah] & [xamsah] & $\mathrm{A}$ & A & $\wedge$ & & & \\
\hline 131 & Ludah & {$\left[? i d^{h} u\right]$} & {$[b u s ̧ \bar{a} q]$} & $\mathrm{A}$ & $\mathrm{B}$ & & & & \\
\hline 132 & Lurus & [?alatul] & [mustaqīm] & $\mathrm{A}$ & B & & & & \\
\hline 133 & Lutut & [rukbah] & {$[$ rukbah] } & $\mathrm{A}$ & $\mathrm{A}$ & $\wedge$ & & & \\
\hline 134 & Main & {$[l a ? \partial p]$} & {$[l a \& b]$} & $\mathrm{A}$ & $\mathrm{A}$ & & & & $\wedge$ \\
\hline 135 & Makan & [kvl] & {$[\mathrm{kul}]$} & $\mathrm{A}$ & $\mathrm{A}$ & & & & $\wedge$ \\
\hline 136 & Malam & {$[l \varepsilon l]$} & [lail] & A & A & & $\wedge$ & & \\
\hline 137 & Mata & [?aIn] & [Gain] & $\mathrm{A}$ & A & & $\wedge$ & & \\
\hline 138 & Matahari & [šamson] & [šamsun] & $\mathrm{A}$ & $\mathrm{A}$ & & & & $\wedge$ \\
\hline 139 & Mati & [tufi] & [tuwuffi] & A & A & & $\wedge$ & & \\
\hline 140 & Merah & [?ahmar] & [?ahmar] & $\mathrm{A}$ & $\mathrm{A}$ & $\wedge$ & & & \\
\hline 141 & Mereka & [ha?ula?] & [hā?ula?] & $\mathrm{A}$ & $\mathrm{A}$ & $\wedge$ & & & \\
\hline 142 & Minum & {$[s r O p]$} & [?israb] & $\mathrm{A}$ & $\mathrm{A}$ & & & $\wedge$ & \\
\hline 143 & Mulut & [mulvt] & [fam $]$ & $\mathrm{A}$ & B & & & & \\
\hline
\end{tabular}


Jurnal CMES Volume X Nomor 2 Edisi Juli - Desember 2017

Program Studi Sastra Arab FIB UNS Surakarta

\begin{tabular}{|c|c|c|c|c|c|c|c|c|c|}
\hline 144 & Muntah & [muntah] & {$[y a q \bar{\imath} \hat{\imath} u]$} & $\mathrm{A}$ & $\mathrm{B}$ & & & & \\
\hline 145 & Nama & [?isəm] & [?ism] & $\mathrm{A}$ & $\mathrm{A}$ & $\wedge$ & & & \\
\hline 146 & Napas & [napas] & {$[n a f s]$} & $\mathrm{A}$ & $\mathrm{A}$ & & & & $\wedge$ \\
\hline 147 & Nyanyi & [3azi] & [yarnī] & $\mathrm{A}$ & $\mathrm{B}$ & & & & \\
\hline 148 & Orang & [?insan] & [?insān] & $\mathrm{A}$ & $\mathrm{A}$ & $\wedge$ & & & \\
\hline 149 & Panas & [har $]$ & {$[h \bar{a} r]$} & $\mathrm{A}$ & $\mathrm{A}$ & $\wedge$ & & & \\
\hline 150 & Panjang & {$[t O w I l]$} & {$[t \bar{a} w I l]$} & $\mathrm{A}$ & $\mathrm{A}$ & & $\wedge$ & & \\
\hline 151 & Pasir & [pasir] & [ramāl $]$ & $\mathrm{A}$ & $\mathrm{B}$ & & & & \\
\hline 152 & Pegang & [megan] & [yumsiku] & $\mathrm{A}$ & B & & & & \\
\hline 153 & Pendek & [kOsIr] & [qaşī $r]$ & $\mathrm{A}$ & $\mathrm{A}$ & & $\wedge$ & & \\
\hline 154 & Peras & [maras] & [Saşara] & $\mathrm{A}$ & $\mathrm{B}$ & & & & \\
\hline 155 & Perempuan & [harım] & [harim] & $\mathrm{A}$ & $\mathrm{A}$ & & $\wedge$ & & \\
\hline 156 & Perut & [batan] & {$[b a T n]$} & $\mathrm{A}$ & $\mathrm{A}$ & & & $\wedge$ & \\
\hline 157 & Pikir & {$[\operatorname{pikir}(m)]$} & [fikr] & $\mathrm{A}$ & $\mathrm{A}$ & & & & $\wedge$ \\
\hline 158 & Pohon & [šajarOh] & [šajarah] & $\mathrm{A}$ & $\mathrm{A}$ & $\wedge$ & & & \\
\hline 159 & Potong & {$[\mathrm{mOtO \eta}]$} & [qaTaSa] & $\mathrm{A}$ & $\mathrm{B}$ & & & & \\
\hline 160 & Punggung & 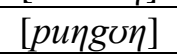 & [dahr] & $\mathrm{A}$ & B & & & & \\
\hline 161 & Pusar & {$\left[? \mathrm{ud}^{h} \mathrm{el}\right]$} & [dawaran] & $\mathrm{A}$ & $\mathrm{B}$ & & & & \\
\hline 162 & Putih & [?abyat] & [?abyad] & $\mathrm{A}$ & $\mathrm{A}$ & & & $\wedge$ & \\
\hline 163 & Rambut & [sa? $\mathrm{s}]$ & {$[\mathrm{saYr}]$} & $\mathrm{A}$ & $\mathrm{A}$ & & & & $\wedge$ \\
\hline 164 & Rumput & [hasis] & [hašššs & $\mathrm{A}$ & $\mathrm{A}$ & & & & $\wedge$ \\
\hline 165 & Satu & [wahtt] & [wahid] & $\mathrm{A}$ & $\mathrm{A}$ & & & $\wedge$ & \\
\hline 166 & Saya & [?ana] & {$[? a n \bar{a}]$} & $\mathrm{A}$ & $\mathrm{A}$ & $\wedge$ & & & \\
\hline 167 & Sayap & [sayap] & [janāh] & $\mathrm{A}$ & $\mathrm{B}$ & & & & \\
\hline 168 & Sedikit & {$[\mathrm{gOlil}]$} & [qalīl] & $\mathrm{A}$ & $\mathrm{A}$ & & $\wedge$ & & \\
\hline 169 & Sempit & [Siye?] & [doyyiq] & $\mathrm{A}$ & $\mathrm{A}$ & & & & $\wedge$ \\
\hline 170 & Semua & [kulvh] & [kulluh] & $\mathrm{A}$ & $\mathrm{A}$ & & & & $\wedge$ \\
\hline 171 & Siang & [nahar] & [nahār & $\mathrm{A}$ & $\mathrm{A}$ & $\wedge$ & & & \\
\hline 172 & Siapa & [man] & {$[\mathrm{man}]$} & $\mathrm{A}$ & $\mathrm{A}$ & $\wedge$ & & & \\
\hline 173 & Suami & [zavt] & [zauj] & $\mathrm{A}$ & $\mathrm{A}$ & & & & $\wedge$ \\
\hline 174 & Sungai & [nahor] & [nahr] & $\mathrm{A}$ & $\mathrm{A}$ & $\wedge$ & & & \\
\hline 175 & Tahu & [ya?rIf] & [yaGrif] & $\mathrm{A}$ & $\mathrm{A}$ & & $\wedge$ & & \\
\hline 176 & Tahun & [sanah] & [sanah] & $\mathrm{A}$ & $\mathrm{A}$ & $\wedge$ & & & \\
\hline 177 & Tajam & [tajam] & [hāddun] & $\mathrm{A}$ & B & & & & \\
\hline 178 & Takut & [faza?] & {$[f a z a S a]$} & $\mathrm{A}$ & $\mathrm{A}$ & & & & $\wedge$ \\
\hline 179 & Tali & [tali $]$ & {$[$ habl] } & $\mathrm{A}$ & B & & & & \\
\hline 180 & Tanah & [?arat] & [ard] & $\mathrm{A}$ & $\mathrm{A}$ & & & $\wedge$ & \\
\hline 181 & Tangan & [yat] & [yad] & $\mathrm{A}$ & $\mathrm{A}$ & & & $\wedge$ & \\
\hline 182 & Tarik & {$[j a \delta \partial p]$} & {$[j a \delta b]$} & $\mathrm{A}$ & $\mathrm{A}$ & & & $\wedge$ & \\
\hline 183 & Tebal & {$\left[\right.$ kand $\left.^{h} e l\right]$} & [Yalīd] & $\mathrm{A}$ & $\mathrm{B}$ & & & & \\
\hline 184 & Telinga & {$[u \delta u n]$} & 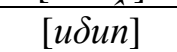 & $\mathrm{A}$ & $\mathrm{A}$ & $\wedge$ & & & \\
\hline 185 & Telur & {$[b \varepsilon t]$} & [baid] & $\mathrm{A}$ & A & & & $\wedge$ & \\
\hline 186 & Terbang & [mabor] & [yaTîru] & $\mathrm{A}$ & $\mathrm{B}$ & & & & \\
\hline 187 & Tertawa & [ияиуи] & [yadhaku] & $\mathrm{A}$ & $\mathrm{B}$ & & & & \\
\hline 188 & Tetek & [laban] & {$[l a b n]$} & $\mathrm{A}$ & A & $\wedge$ & & & \\
\hline 189 & Tidak & [la?] & {$[l \bar{a}]$} & $\mathrm{A}$ & $\mathrm{A}$ & & $\wedge$ & & \\
\hline 190 & Tidur & [ragot $]$ & {$[$ ruqūd $]$} & A & A & & $\wedge$ & & \\
\hline 191 & Tiga & [OalaAah] & {$[$ [Aalā $\theta a h]$} & $\mathrm{A}$ & $\mathrm{A}$ & $\wedge$ & & & \\
\hline 192 & Tikam(me) & [nusv?] & [yaTSanu] & $\mathrm{A}$ & $\mathrm{B}$ & & & & \\
\hline
\end{tabular}




\begin{tabular}{|c|c|c|c|c|c|c|c|c|}
\hline 193 & Tipis & {$[\mathrm{rOgig}]$} & {$[$ raqī $q]$} & A & A & & $\wedge$ & \\
\hline 194 & Tiup & [nivp] & [yanfuxu] & A & B & & & \\
\hline 195 & Tongkat & {$[t u \eta k \partial t]$} & [Gaşo:] & A & B & & & \\
\hline 196 & Tua & [?ajus] & [?ajūz] & $\mathrm{A}$ & $\mathrm{A}$ & & & $\wedge$ \\
\hline 197 & Tulang & [tula $]$ & [Gadm] & A & $\mathrm{B}$ & & & \\
\hline 198 & Tumpul & {$\left[k \partial t^{h} \sigma l\right]$} & [kalìl $]$ & A & B & & & \\
\hline 199 & Ular & [hanat] & [hanā $\theta]$ & $\mathrm{A}$ & $\mathrm{A}$ & $\wedge$ & & \\
\hline 200 & Usus & [usvs] & [miS:] & $\mathrm{A}$ & B & & & \\
\hline
\end{tabular}

Penghitungan

persentase

kekerabatan antara bahasa Pasar Kliwon Surakarta dengan bahasa Arab dilakukan dengan membagi pasangan kata kerabat yang ditemukan dengan jumlah keseluruhan kata yang memiliki pasangan. Jumlah keseluruhan kata yang memiliki pasangan kata dalam kedua bahasa yaitu lengkap 200 pasang. Sedangkan dari jumlah tersebut, ditemukan 136 kata yang berkerabat karena telah memenuhi empat syarat kekerabatan. Persentase kekerabatan antara kedua bahasa dapat dihitung dengan menggunakan rumus berikut:

$$
\mathrm{C}=\frac{k}{n} 100 \%=\frac{136}{200} 100 \%=
$$$$
0,68 \cdot 100 \%=68 \%
$$

Persentase kata kerabat yang diperoleh dengan membandingkan kata yang berkerabat dengan keseluruhan kata yang berpasangan yaitu sebesar $68 \%$.

Persentasi kekerabatan tersebut dapat menjelaskan jarak kedua bahasa yang diteliti. Berdasarkan pengelompokan yang dikemukakan oleh Ayatrohaedi (1983: 32) menunjukkan bahwa bahasa Pasar Kliwon Surakarta dengan bahasa Arab masuk ke dalam kelompok perbedaan dialek. Hal ini disebabkan karena kedua bahasa memiliki persentase sebanyak $68 \%$. Klasifikasi bahasa yang menyatakan bahwa relasi bahasa Pasar Kliwon Surakarta dengan bahasa Arab adalah dialek, senada dengan pengertian dialek yang dikemukakan oleh Chaer dan Agustina (2010: 63) bahwa dialek adalah variasi bahasa dari sekelompok penutur yang jumlahnya relatif, yang berada dalam suatu wilayah atau area tempat tinggal penutur. Namun, hal tersebut tidak sampai menyebabkan perbedaan bahasa.
Oleh karena itu, ciri utama dialek adalah perbedaan dalam persamaan dan persamaan dalam perbedaan (Ayatrohaedi, 1983: 1-2).

2. Penghitungan waktu pisah

Penghitungan waktu pisah digunakan untuk mengetahui dua bahasa tersebut mulai berpisah dari bahasa yang sama sehingga dapat diketahui waktu bangsa Arab datang ke Indonesia dan melakukan interaksi dengan masyarakat setempat. Penghitungan waktu pisah antara bahasa Pasar Kliwon Surakarta dengan bahasa Arab dilakukan setelah mengetahui persentase kekerabatannya, yaitu 68\%. Waktu pisah antara dua bahasa kerabat tersebut dapat dihitung dengan menggunakan rumus berikut:

$$
\begin{array}{r}
w=\frac{\log c}{2 \log r}=\frac{\log 0,68}{2 \log 0,81}=\frac{-0,167}{2(-0,092)} \\
=\frac{-0,167}{-0,184}=0,908
\end{array}
$$

Perhitungan waktu pisah antara bahasa Pasar Kliwon Surakarta dengan bahasa Arab adalah 0,908 ribuan tahun yang lalu, atau dengan kata lain bahwa bahasa kedua bahasa tersebut, mulai berpisah kira-kira pada abad XII Masehi.

Hasil perhitungan tersebut bukan merupakan tahun pasti kedua bahasa itu berpisah, maka harus ditetapkan suatu jangka waktu perpisahan itu terjadi. Oleh karena itu, harus diadakan perhitungan tertentu untuk menghindari kesalahan semacam itu. Jadi, masih diperlukan teknik statistik berikutnya, yaitu jangka kesalahan.

3. Penghitungan jangka kesalahan

Cara yang digunakan untuk menghindari kesalahan dalam statistik adalah memberi suatu perkiraan bahwa suatu hal terjadi bukan dalam waktu 
tertentu, tetapi dalam suatu jangka tertentu. Jangka kesalahan terjadi akumulasi perbedaan-perbedaan antara kedua bahasa tersebut, yang sekian hari bertambah besar, sehingga perlahan-lahan tapi pasti dapat menandai perpisahan antara kedua bahasa.

Penghitungan jangka kesalahan biasanya dipergunakan kesalahan standar, yaitu $70 \%$ dari kesalahan yang diperkirakan. Kesalahan standar dapat dihitung menggunakan rumus berikut:

$\mathrm{S}=\sqrt{\frac{C(1-C)}{n}}=\sqrt{\frac{0,68(1-0,68)}{200}}=$

$\sqrt{\frac{0,68(0,32)}{200}}=\sqrt{\frac{0,2176}{200}}=$

$\sqrt{0,00109}=0,033$

Perhitungan tersebut menunjukkan bahwa kesalahan standar dalam persentase kata kerabat yaitu 0,033 (dibulatkan menjadi 0,03).Hasil dari kesalahan standar tersebut dijumlahkan dengan persentase kerabat untuk mendapatkan $\mathrm{C}$ baru.

$$
\mathrm{C} \text { baru }=0,03+0,68=0,71
$$

Setelah mendapatkan $\mathrm{C}$ yang baru, maka dapat dilakukan perhitungan ulang waktu pisah menggunakan rumus waktu pisah, yaitu sebagai berikut:

$\mathrm{W}=\frac{\log C}{2 \log R}=\frac{\log 0,71}{2 \log 0,81}=\frac{-0,149}{2(-0,092)}=$ $\frac{-0,149}{-0,184}=0,81$

Perhitungan waktu pisah baru adalah 0,81 ribu tahun yang lalu, atau 810 tahun Masehi yang lalu. Seperti yang telah dikemukakan di atas untuk memperoleh jangka kesalahan, maka waktu yang lama dikurangi dengan waktu yang baru, yaitu: $908-810=98$. Angka ini harus ditambah dan dikurangi dengan waktu yang lama untuk memperoleh usia atau waktu pisah antara bahasa Pasar Kliwon Surakarta dengan bahasa Arab, yaitu $908-98=810$ dan $908+98=$ 1006.

Berdasarkan perhitungan angka dalam jangka kesalahan pada kesalahan standar, maka umur atau usia antara kedua bahasa dapat dinyatakan sebagai berikut:

a. Bahasa Pasar Kliwon Surakarta dan Arab merupakan bahasa yang sama pada 810 - 1006 tahun Masehi yang lalu.

b. Bahasa Pasar Kliwon Surakarta dan Arab mulai berpisah dari suatu bahasa yang sama antara tahun 1.011 Masehi sampai 1.207 Masehi (dihitung dari tahun 2.017 Masehi).

Waktu pisah antara bahasa Pasar Kliwon Surakarta dengan bahasa Arab yaitu antara abad XI-XII Masehi. Hal ini sejalan dengan teori kedatangan masyarakat Hadramiy ke Indonesia. Kedatangan masyarakat Hadramiy ke Indonesia terbagi menjadi 4 gelombang (Kafaabillah, 2015: 1). Gelombang pertama dimulai sejak abad XII Masehi, yaitu sejak kedatangan golongan Alawiyyin dari marga Syahab ke Siak. Misi kedatangan gelombang pertama ini adalah untuk mendakwahkan ajaran Islam.

Kedatangan masyarakat Hadramiy ke Indonesia juga disampaikan oleh Algadri (1984: 37-40). Fakta peninggalan sejarah membuktikan bahwa pada awal abad XI diketemukan suatu makam di desa Leran Jawa Timur dekat Surabaya. Makam tersebut bertuliskan Arab di atas nisan dengan nama Fatimah binti Mansur bin Hibatallah. Makam dan tulisan tersebut membuktikan bahwa abad XI bangsa Arab telah masuk ke Indonesia.

\section{KESIMPULAN}

Berdasarkan data yang diperoleh di lapangan, kemudian dianalisis, dan telah mendapatkan hasilnya dari perhitungan leksikostatistik pada tataran kosakata, maka dapat disajikan simpulan analisis yang berkaitan dengan butir-butir rumusan masalah dan tujuan penelitian sebagai berikut.

1. Berdasarkan data yang diperoleh dari 200 kosakata Swadesh, terdapat 200 pasangan kata lengkap dan memiliki padanan kata dari kedua bahasa. Pasangan kata tersebut menunjukkan kekerabatan dengan pengklasifikasian sebagai berikut: 
a. 62 pasangan kata kerabat yang identik dari 136 seluruh pasangan kata berkerabat, dengan persentase $45,6 \%$

b. 30 pasangan kata kerabat yang memiliki korespondensi fonemis dari 136 seluruh pasangan kata kerabat, dengan persentase $22,1 \%$

c. 17 pasangan kata kerabat yang memiliki kemiripan fonetis dari 136 seluruh pasangan kata kerabat, dengan persentase $12,5 \%$

d. 27 pasangan kata yang memiliki satu fonem berbeda dari 136 seluruh kata berkebatan, dengan persentase $19,9 \%$

2. Berdasarkan data yang ditemukan, terdapat 136 pasangan kata yang berkerabat, atau sebesar $68 \%$. Presentase menunjukkan bahwa bahasa Pasar Kliwon merupakan sebuah dialek dari bahasa Arab.

3. Berdasarkan waktu pisah antara bahasa Pasar Kliwon Surakarta dengan bahasa Arab, dinyatakan bahwa kedua bahasa merupakan bahasa yang sama pada 810 1006 tahun Masehi yang lalu, atau dapat dikatakan antara tahun 1.011 Masehi sampai 1.207 Masehi (dihitung dari tahun 2.017 Masehi).

\section{DAFTAR PUSTAKA}

Algadri, Hamid. 1984. C Snouck Hurgronje: Politik Belanda terhadap Islam dan Keturunan Arab. Jakarta: sinar Harapan.

Ayatrohaedi. 1983. Dialektologi: Sebuah Pengantar. Jakarta:

Chaer, Abdul dan Leonie Agustina. 2010. Sosiolinguistik: Perkenalan Awal. Jakarta: Rineka Cipta.
Kafaabillah, Dita dan Muhammad Ridwan. 2015. "Nama-nama Marga Keturunan Arab di Pasar Kliwon Surakarta. Surakarta: UNS Skripsi.

Keraf, Gorys. 1996. Linguistik Bandingan Historis. Jakarta: PT Gramedia.

Mahsun. 1995. Dialektologi Diakronis: Sebuah Pengantar. Yogyakarta: Gadjah Mada University Press.

Sudaryanto. 2015. Metode dan Aneka Teknik Analisis Bahasa. Yogyakarta: Sanata Dharma University Press.

Widyastuti, Sri Surami. 2006. Skripsi. "Perkembangan Usaha Batik Masyarakat Keturunan Arab di Pasar Kliwon". Surakarta: UNS Skripsi.

Zunainingsih, Memik. 2010. "Sekolah Islam Diponegoro Surakarta Tahun 1966-2005". Surakarta: UNS Skripsi. 